\title{
The Impact of Globalization and International Tax Competition on Tax Policies
}

\author{
Alla Sokolovska ${ }^{1}$, Tetyana Zatonatska ${ }^{2}$, Andriy Stavytskyy ${ }^{2}$, Oleksii Lyulyov $^{3} \&$ Vincent Giedraitis $^{4}$ \\ ${ }^{1}$ State Educational and Scientific Establishment “Academy of Financial Management”, Ukraine \\ ${ }^{2}$ Taras Shevchenko National University of Kyiv, Ukraine \\ ${ }^{3}$ Sumy State University, Ukraine \\ ${ }^{4}$ Vilnius University, Lithuania \\ Correspondence: Andriy Stavytskyy, Taras Shevchenko National University of Kyiv, Vasylkivska-str, 90a, Kyiv, \\ Ukraine, 03022. Tel: 380-67-755-5647. E-mail: a.stavytskyy@gmail.com
}

Received: June 23, 2020

doi:10.5430/rwe.v11n4p1
Accepted: July 30, 2020

Online Published: August 14, 2020

URL: https://doi.org/10.5430/rwe.v11n4p1

\begin{abstract}
The aim of the paper is to determine to what extent the strengthening of the transparency of the Ukrainian economy and its incorporation in international tax competition affects the tax policy of the country and the peculiarities of its tax system. In the study, the logical analysis of the direct and inverse relationship of changes in taxation with such manifestations of globalization, as the movement of capital and labor resources from Ukraine and to the country, is combined with an empirical (regression) analysis of the relationship between globalization and the main characteristics of the Ukrainian tax system. It is proved that the increase of incorporation of Ukraine in globalization processes, despite the reduction of taxes on the main factors of production, is accompanied by an increase in the general level of tax burden on the economy (tax rate). The above mentioned is a consequence of increase of other taxes, including excise, caused both by internal needs of Ukraine (conducting the policy of fiscal consolidation caused by large public debt, and increasing defense expenditures) and its international obligations (EU Association Agreement). The tax system in Ukraine is much stronger (about 25\%) influenced by the general index of globalization in comparison with its subindex characterizing the economic component of globalization. Obviously, this is owing to the greater influence on taxation in Ukraine of other components of globalization such as political and social one. The results show that the growth of the globalization index is accompanied by rather expected effects such as reduction of corporate profit tax rates and personal income tax, transferring the tax burden from capital to labor and, to a greater extent, on consumption, improving business conditions in the context of tax payments, and specific increase in the general level of tax burden on the economy, significant losses of the state that is not so much from the reduction of tax rates as from the erosion of the tax base on income, which is the result of a combination of negative effects of external and internal factors; the threat of escalating the policy of low tax rates. It is recommended to the Ukrainian Government to focus increasingly on the tax evolution trends in post-socialist EU countries to strengthen Ukraine`s position in tax competition with this group of countries.
\end{abstract}

Keywords: globalization, tax competition, tax policy, tax system

\section{JEL Classification: F38, H71}

\section{Introduction}

In the second half of the 20th century -the beginning of the 21st century, the crucial factor in the transformation of national tax system and tax policies is becoming the globalization of the system of world economic relations (Singh, 2019a; Singh, 2019b), which, according to S.Gyglia (2018), "is a process that blurs national boundaries, integrates national economies, cultures, technology and management, and creates complex relationship of mutual dependence" ("Globalization is a process that erodes national boundaries, integrates national economies, cultures, technologies and governance, and produces complex interactions of mutual interdependence"). New phenomena in the economy, ecology and other spheres of social life (Bilan, 2019 a; Bilan, 2019 b; Bilan, 2019 c; Chygryn et al., 2018; Cebula et al., 2018), caused by globalization, fundamentally changed not only external but also internal conditions of the formation of national tax systems, determined the vector of their transformation, necessitated the development of a 
national tax policy considering the tax policy of countries-potential competitors for foreign investment and labor resources (Miller, 2019; AUgbakamet al, (2019); Voronkova et al., 2019; Kwilinski 2019). All mentioned leads to the relevance of the study not only of the overall tax consequence of globalization, but also its impact on the tax policies of certain countries, the peculiarities of which are determined not only by external factors, but also by internal factors-the needs of the national economy, the interests of all interested parties, the level of development of institutions, those who perform the function of tax administration.

Ukraine began to form its tax system on its achievement of independence in the early 90's of the last century. Since then, its tax system has undergone significant transformations that have been shaped by the effects of more than one tax reform. Meanwhile, the process of gradual integration of the Ukrainian economy into the world economic system took place. For the time being, Ukraine is an open country, quite integrated into the global world. The level of its globalization, measured by the KOF globalization index (2018), has increased from 34.76 in 1991 (the value of the overall indicator) to 74.25 in 2016. By this indicator, it ranked 42nd among 203 countries of the world.

The aim of the article is to determine to what extent the strengthening of the transparency of the Ukrainian economy and its incorporation in international tax competition affects the tax policy of the country and the peculiarities of its tax system. The achievement of this aim involves a delineation of changes in national tax policies that occur in response to the migration of mobile factors of production (in other words, under the influence of "true tax competition" as defined by Roxan (2012) and those caused by the influence of internal factors - economic, political, social.

\section{Literature Review}

Many modern studies have been devoted to the impact of globalization and international tax competition on national tax systems and tax policies. Analyzing their achievements, we first of all turn to the definition of the conceptual framework of the relationship of the above-mentioned phenomena. It means that globalization, by destroying the barriers to the interstate movement of capital, labor, goods and services, increases their mobility. The latter generates international tax competition, which is an "uncoordinated tax" when the country is "restricted by the behavior of other countries" in determining its tax policy, according to Devereux (2013). The mechanism of tax competition lies in the fact that countries, in order to preserve and attract the mobile factors of production, should offer attractive tax regimes, including lower effective tax rates.

Studying the interstate mobility of production factors as the basis for tax competition, scientists focus on the following aspects of the problem:

1) higher mobility of capital in comparison with labor, which leads to a reduction in taxes on capital and the transfer of tax burden on labor (Wilson, 1999; Zodrow, 2003; Buriak, 2015; Bilan, 2018). In extreme cases, tax competition leads to a "race to the bottom" in which countries abandon the taxation of capital gains and rely solely on the taxation of income from labor and consumption. At the same time, according to Reuven (2000), there are factors that counteract the reduction of the tax rate to the minimum allowable level. It is a good infrastructure and skilled workers who are needed not only for attracting but also for the effective use of foreign investments in the country. In turn, both the high quality of public infrastructure and the high quality of the education system require a certain level of public funding, which provides the rejection of low tax policies. Thus, foreign investors face a choice: either to invest in a country with moderate taxes and a developed social sector or in a country with low taxes and a small public sector. Eventually, their choice will be determined by the ratio of the loss of income generated by the payment of taxes, and the benefits of public goods and services received in exchange for taxes from the government of capital investment;

2) differentiation of capital types by degree of mobility: some types of financial capital, in particular, instruments traded on international stock exchanges of securities, both very mobile and physical capital (investments in real production capacity) as less mobile (Tiutiunyk, 2019);

3) justifying the tax consequences of mobility not only for capital, but also for labor, as well as the varying degrees of mobility of highly skilled and unskilled workers. In particular, in the work of Kleven et al. (2013) presents convincing evidence of the link between taxation and international labor migration and argues that the mobility of highly skilled workers limits the ability of the country to raise income taxes. Another work devoted to the study of the impact of competition globalization on highly skilled and highly paid labor on the tax policy of OECD countries is Egger et al. (2016). In the work, according to the analysis of changes in the effective tax rates on labor income in the 65 largest economies for the period from 1980 to 2007, has been established that since the mid-1990s, due to the reduction of the tax burden on skilled high-income workers who, through higher mobility more easily avoid high 
taxes, OECD governments are increasingly relocating an additional tax burden on the middle class. According to Hellier (2018), this phenomenon in the last three decades takes place in the vast majority of developed countries. This has enabled to draw conclusion that globalization generates and strengthens the trade-off between less redistribution and less progressive taxation;

4) Identified reasons for the increase in the mobility of low-skilled workers, which are attracted to welfare countries by high levels of social standards, what is pointed by Cohen (2008).

Keuschnigg (2009) investigates the impact of corporate taxation and social insurance on foreign direct investment and unemployment, concluding that their influence is identical. An increase in the corporate tax rate, although it may increase the amount of income tax, is likely to worsen the general government fiscal stance. Due to a decrease in the total volume of investments and their outflow abroad, the corporate tax base is narrowing, as well as unemployment rising, therefore the government suffer double losses. It should spend more on social payments and, at the same time, collect less income from taxes (both corporate and payroll taxes). Thus, in order to balance the budget, the government needs to increase even more the wage tax.

The growth of social expenditures, financed by wage tax incomes, requires an increase in the tax burden on employees. As wage taxes are partly transferred to employers, this reduces the income of domestic firms, and hence tax incomes from corporations. As a result, not only general investments are reduced, but most of them are sent to foreign countries with lower wages. National employment is declining. Consequently, the expansion of the state of social welfare increases wages, reduces profits and national investment, as well as the creation of new jobs, causing an increase in investment in the economy of foreign countries.

A wide range of tax consequences of not only international tax competition, but also other phenomena of a globalized economy is covered in Tanzi's works (1996), (2005). Including:

- reduction of excise taxes and sales tax, especially for goods that are expensive and easily transported, owing to the intensification of cross-border trade;

- the narrowing of the tax base for consumption through e-commerce, which results in the sale of a significant number of goods and services over the Internet without paying taxes;

- complication of control over economic transactions subject to taxation, through the use of electronic money;

- transfer of profits from high tax rates to lower-interest countries, which helps to reduce the tax burden on multinational corporations through the use of transfer pricing;

- tax evasion and avoidance from the use of offshore financial centers and tax havens, as well as new financial instruments such as different categories of derivatives, many of which have been developed precisely for this purpose, which becomes possible due to insufficient regulation of tax legislation on this issue;

- tax evasion derived from activities abroad, which is possible due to the lack of information exchange between tax authorities of different countries.

According to Tanzi (1996), the consequence of all these phenomena may be a reduction in tax incomes for many countries and a forced change in the structure of their tax systems, sometimes defined as "tax degradation," as well as a reduction in the progressiveness of taxation, making it less equitable.

On the other hand, the consequence of globalization and tax competition is the expansion of a potential tax base of the country due to the use of tax bases of other countries. In particular, a country can involve and tax: foreign financial capital; foreign real capital in the form of direct investment; foreign consumers; foreign workers, etc. Hence, the "world tax base" becomes a kind of "shared resource" that all countries can try to use in their favor (Tanzi, 2005).

Ultimately, according to Tanzi (2005), some countries win, while others lose from globalization and tax competition. Those who can involve foreign capital and labor force, as a result expands the tax base will benefit. Countries that lose their tax base due to the outflow of capital and labor resources get loos. In this case, the flow of resources to the country or in the opposite direction depends on the following factors: the statutory tax rates; tax burden, that is, the ratio of taxes to GDP or other special tax bases ; administrative and tax compliance costs; predictability of tax policy; legal transparency, i.e. clarity of tax legislation; the volume and quality of services received by residents or enterprise from the government un exchange for paid taxes; budget deficits and public debt, as they can lead to higher taxes in the future; and, in general, the economic or investment climate in the country. 
The idea of the various effects of international tax competition and globalization for different countries has been further developed in Genschel and Seelkopf (2016). They identified three factors influencing international competitive constrains on national tax policies:

- size of the country: small countries have stronger incentives for competitive tax cuts and ultimately set their lower rates. At the same time, fiscal stress in these countries is lower than in the big ones;

- type of regime: the winners of tax competition, for the most part, are democratic countries. Their governments, oriented toward the well-being of their populations, are more sensitive to the effects of tax policies than autocratic governments. They seek to reduce taxes if their country is small enough to potentially benefit from tax competition and strive to maintain the existing level of taxes (or pursue a moderate policy of reducing them) if their country is large enough;

- state potential (the state's ability to guarantee the rule of law and administrative efficiency, that is, the ability to ensure effective tax administration). However, state capacity varies widely not only between different types of regimes, but also within the same type, depending on the level of economic development. The paper substantiates that less developed countries with low public potential are less able to take advantage of the potential benefits of tax competition and, at the same time, are less able to cope with its adverse financial implications. Consequently, fiscal winners in the context of economic globalization, as a rule, have small, well-governed democracies.

Onaran and Boesch (2014) assessed the impact of globalization on labor taxes and social expenditures in welfare states with different political regimes. As a result of the study, it was found that in countries with conservative regimes, due to globalization both social expenditures and labor taxes increase. In socio-democratic states, globalization does not affect social spending, the burden of which is increasingly borne by implicit tax rates on labor, while imlicit tax rates on capital and consumption are shrinking. In liberal regimes, implicit tax rates on labor are increasing, while social spending is shrinking. In south European countries, globalization does not have a significant impact on the distribution of taxes or social costs. In countries of Eastern Europe and the Baltics, globalization leads to a reduction in social costs, while in other Eastern European emerging EU countries (in the post-communist European regimes), convergence of social expenditures occurs through globalization. The implicit rates of consumption taxes in post-communist European countries are decreasing, while in the Baltic countries there is no sustained significant impact of globalization on taxes.

Merkulova (2013) investigated the impact of the level of technological development of the country and its size on the possibility of maximizing capital tax incomes in the context of tax competition. Considering various cases of competition between countries, the author concluded that in the competition of low-tech countries, small countries find themselves in a more difficult situation if their competitor pursues a policy of low tax rates and benefits if the competitor pursues a policy of high rates. High-tech rivals that compete with one another cannot maximize their incomes with a bet - the optimal level is unrealistically high. The tax policy of less technologically advanced countries has almost no effect on the optimal tax rate in high-tech countries.

Luković (2015) conducted an empirical study on the impact of globalization and international tax competition on tax characteristics in European countries. The hypothesis discussed in his paper is that the differences between the national tax systems of the group of countries that were the subject of the study can be explained by the differences in the level of their involvement in the process of globalization. As a result of the analysis, it has been established that tax competition and globalization (its indicator is selected by three sub-indexes - economic, social and political, which constitute the CSGR Globalization Index) have a significant impact on the size of basic tax rates (corporate income, value added, and individual incomes), while their impact on the level of tax burden on business activity (its indicators were defined in the World Bank's Doing Business report: the total tax rate is TTR, the number of tax payments per the year and time required to complete all tax procedures) is less pronounced.

Reuven (2000) analyzes such a consequence of globalization and tax competition as the fiscal crisis of a charitable state. It is noted that developed countries responded in two ways on the reduction of profit tax rates as a tool for involving investment: firstly, by transferring the tax burden from mobile capital to less mobile work, and, secondly, when increased taxation on labor became politically and economically problematic, by reducing social expenditures. Thus, globalization and tax competition lead to fiscal crises in countries that want to continue to develop social insurance. At the same time, demographic factors and increasing income inequality, job insecurity, and the instability of incomes arising from globalization make this social insurance increasingly necessary. These crises force countries to restrict globalization, which can lead to a reduction in world welfare. The article argues that the preservation of both phenomena-globalization and social insurance will require measures that restrict tax competition, but retain the ability of each democratic state to determine the size of the public sector. 
The mechanism of the impact of globalization and international tax competition on tax policy and tax systems, as well as an empirical analysis of the peculiarities of such influence in countries of differing size, political regimes, level of openness to the outside world, level of development of institutions and economic development are disclosed in the process of theoretical research and is the methodological basis for our study. The emphasis on tax policy in Ukraine in the context of external and internal influences on the process of its formation will make it possible to reveal the peculiarities of globalization effects for a small transparent economy whose tax policy is formed under the influence of contradictory factors - not only tax competition for mobile factors of production, but also significant fiscal constraints caused by a large public debt, significant social obligations of the state, rising budget expenditures on defense and security.

\section{The Methodological Basis for the Research}

The study of the impact of globalization on tax policy in Ukraine was carried out by combining a logical analysis of the direct and inverse relationship of changes in taxation with such manifestations of globalization as the movement of capital and labor resources from Ukraine and the country, with an empirical (regression) analysis of the interconnection between globalization (the magnitude of its index and subindex characterizing its economic dimension) and the following characteristics of the tax system of Ukraine, such as:

1) rates of corporate income tax and personal income tax;

2) the structure of the tax system;

3) the total tax burden on the economy (tax rate);

4) the number of payments per year and the time spent on paying taxes.

In addition, the effect of the World Bank's Doing Business Ratings by category of taxation (amount of payments, time to fulfill the tax liability, share of taxes on profits) on Ukraine's FDI dynamics is investigated.

The first part of the study made it possible to assume the role of globalization in changing taxation in Ukraine and to formulate hypotheses about the directions of its influence on the main characteristics of the tax system. The second is to check them using a quantitative analysis method.

When choosing the basis on which the calculations were made, we relied on the work of Lukovic (2015) and the conclusions of the economic science on the tax consequences of globalization - changes in the rates of basic taxes, the structure of the tax system (it is characterized by the share of individual types of taxes in GDP), the general level of taxation (measured by the tax rate, which represents the ratio of the total amount of taxes, including payments to social funds, to GDP). (Note 1)

In the course of the study, we used available information on the KOF Globalization Index and the subindex of economic globalization in Ukraine, the Paying Tax Indicators in Doing Business (2019), and indicators (share the main taxes in GDP and the tax rate), calculated by us according to the reports of the State Treasury of Ukraine (2019) on the implementation of the consolidated budget revenues of Ukraine and on the implementation of the budgets of the Pension Fund of Ukraine (2019).

In general, the database contains the following variables:

$\mathrm{KOFGl}$ - globalization index KOF;

KOFEcGl - subindex of economic globalization s

The number of tax payments per year (Payments)

The time required to complete all tax procedures (hours per year)

Total tax rate (\% of profit) (TTR)

Enterprise profit tax rate (EPT)

Personal income tax rate (PIT)

VAT rates \%;

Total taxes (including social contributions) as \% of GDP

EPT as \% of GDP - share of income tax on GDP;

PIT as $\%$ of GDP

VAT as $\%$ of GDP 
PII_in - FDI in Ukraine, mln. USA

The calculations used data from 1994, but the lack of certain data made the formation of models with limited samples.

Methodological verification of each hypothesis is based on the estimation of the regression equation of the form (1):

$$
y_{t}=\beta_{0}+\beta_{1} x_{1 t}+\beta_{2} x_{2 t}+\ldots \beta_{k-1} x_{k-1 t}+\varepsilon_{t}
$$

where:

$y_{t}$ - dependent variable, the effect of which will be checked in each hypothesis;

$x_{t j}, t=\overline{1, T}, j=\overline{1, k-1}-$ a set of independent variables, by means of which we will explain the dependent variable;

$\beta_{j}-$ coefficients of the model;

$\varepsilon_{t}-$ the remnants of the model.

Each regression was checked for adequacy, significance of all coefficients, absence of auto-correlation and heteroscedasticity with standard tests.

The calculations have shown that in some cases it is necessary to change the sample for regression construction, as certain tendencies in the tax sphere of Ukraine have begun to respond to global changes only since 2005.

\section{Research Results and Its Discussion}

The growth of the integration of the Ukrainian economy in world economic relations was accompanied by an increase in the inflow of foreign investment in its development. The analysis of their dynamics during 2004-2018 shows that their largest annual revenues were in 2005-2008, when the average annual growth of FDI amounted to $\$ 8.6$ billion. While in 2009-2012 it dropped to $\$ 6.7$ billion, and in the next six years - to $\$ 2.7$ billion according to Direct investments on the principle of orientation (2019). During the five years of the war, Ukraine received fewer foreign investments than in 2008. However, Ukraine was not among the leaders in investing capital in Central and Eastern Europe in 2006-2010 in relatively favorable years for inflow of foreign investments, it occupied $10^{\text {th }}$ place by the number of investment projects (178), and by the number of created jobs (7 487) according to Report on Foreign Direct Investment in Ukraine (2011).

According to the National Bank of Ukraine, the amount of FDI in 2010-2017 made at the expense of domestic origin amounted to $\$ 7.9$ billion the United States or $22 \%$ of the total inflows of foreign direct investment in Ukraine during this period according to Retrospective analysis of data on volumes of direct foreign investments in which the ultimate controlling investor is a resident (round tripping) for 2010-2017 years (2018). The main countries through which such investment was carried out were Cyprus (about half of the total investment), the Netherlands, Switzerland and Austria.

Unlike FDI in Ukraine, in the dynamics of FDI from Ukraine until 2012, there are no clear trends: they are falling (2006, 2009 and 2011), then they grow to over 1 billion dollars. USA (2008 and 2012). Overall, their average annual growth in 2004-2012 was \$ 458.3 million. USA. From 2013 annual investments from Ukraine are sharply reduced, and in 2015 and 2018 their growth in general is of negative significance. As a result, their annual average growth over the last six years was only $\$ 83.2$ million. The lion's share $(94 \%)$ goes to Cyprus, which, according to Ukrainian legislation, does not have an offshore status, provides favorable tax conditions (the tax rate on income is $12.5 \%$ versus $18 \%$ in Ukraine) and the confidentiality of information.

In addition to the legal withdrawal of capital from Ukraine to countries with more favorable tax conditions, its illegal outflow is much larger. According to a study by the NGO Tax Justice Network In "tax oases" hidden over \$ 21 trillion (2019), since the 1990s, \$ 167 billion has been withdrawn from Ukraine to "tax oases" in Switzerland, Luxembourg, Hong Kong, Liechtenstein, Singapore and the Caribbean USA. That is, the annual (during 21 years) capital outflow from the Ukrainian economy amounted to 8 billion dollars, while only a part of these funds returned. The total amount of legally and illegally withdrawn capital from Ukraine in some years could exceed the amount of FDI in Ukraine.

Besides increasing the movement of capital, the growth of the transparency of the Ukrainian economy has led to an increase in the migration of labor resources. As a result, in 2002-2004, the number of people who left the country exceeded the number of those who arrived there. From 2005 to 2016 there is a migration increase, but in 2016 it 
amounted to only 7.8 thousand people, points State Statistics Service of Ukraine (2019). The State Statistics Service of Ukraine does not provide information on internal and external migration in 2017 and 2018. On migration flows in 2017, one can get an idea from the words of the head of the Ukrainian Foreign Ministry, Klimkin, who said that in that year Ukraine left about 100 thousand a month. persons According to the official data of the Ministry of Social Policy, about 3.2 million Ukrainian citizens (on an ongoing basis abroad for the purpose of earning income) are excluded (excluding migrant workers who travel abroad for seasonal work). The main countries of labor migration are Poland, Czech Republic, Italy, Portugal, Spain, Russia.

The withdrawal of capital and labor resources from Ukraine has extremely negative consequences for the economy and the tax system (Druhov et al, 2019): the erosion of the tax base on income and profits, which is aggravated by the influence of internal factors - tax evasion and widespread wage shadowing; structural unemployment (the construction, industry, agriculture, transport and communications are already suffering from a shortage of labor resources); the deterioration of the demographic situation and the quality of human capital (due to the significant outflow of the most active people with higher education).

The size of taxes is one of the factors of the outflow of capital from Ukraine, especially since the main direction of its withdrawal is tax oases. However, it is obvious that taxes are not the only factor of influence, as evidenced by the return of Ukrainian capital to the country in the form of foreign investment.

Taxation trends in the European Union: Data for the EU Member States, Iceland and Norway: 2018 edition (2018) stress that taxes are not a crucial factor and the outflow of labor resources from Ukraine, especially since the main countries of their migration (with the exception of the Czech Republic) have higher maximum rates of income tax (Poland - 32\%, Italy - 47.2, Portugal - 53.0, Spain - 43.5) than Ukraine (18\%). The main reasons for this include: higher wages and social standards; the annexation of the Crimea and the war on the Donbass; visa-free regime with the European Union; programs for the recruitment and retention of migrants by European countries; increase of quotas of European countries for labor migrants from Ukraine. Consequently, taxes affect migration to the extent that they reduce the incomes of Ukrainian citizens, although their revenues would remain significantly lower than the income they receive in European countries, even at low tax rates. In the face of large gaps in the size of both the minimum and the average wage (for example, in Poland and the Czech Republic in 2018 the minimum wage was 503 and 478 euro respectively, the average - 1102 and 1149 euros, and in Ukraine - 121 and 273 euros), the reduction of taxes on income will not have a significant impact on the migration of labor resources from Ukraine to the EU.

All this makes it possible to conclude that the movement of capital and labor resources from Ukraine and to Ukraine is caused by globalization, which opens the boundaries and creates an opportunity for free movement of factors of production. Regarding the impact on them of the magnitude of taxes in Ukraine, although such an influence takes place, it does not play a decisive role. Moreover, the most dynamic inflow of FDI to our country in 2002-2008 was due to the high level of corporate income tax rates (compared with the post-socialist countries of the EU) (30\% during 2002-2003 and 25\% in 2004-2008) against 23.3 and $18.1 \%$ on average in the specified group of countries in 2003 and 2008 respectively.

Analyzing the impact of globalization and international tax competition on tax policy in our country, it should be noted that one of the channels of such influence is the international tax environment - tax policy and tax practice in other countries, the best examples of which are becoming an example for imitation. This is entirely consistent with the Tanzi and Zee (2001) conclusions for countries that want to integrate into the world economy. According to them, the construction of an effective and equitable tax system in such countries is designed to ensure an increase in incomes without excessive government borrowing, and this system itself should not significantly deviate from the tax systems of other countries. For Ukraine, such countries are benchmarks for the formation of its tax policy and the implementation of tax reforms are post-socialist countries - EU members. Changes in the taxation of the countries of this group gave impetus to the following innovations in the tax system of Ukraine:

1) reduction of the corporate profit tax rate in 2004 from 30 to $25 \%$ and during 2011-2014 (in stages) to 18\%. The policy to reduce tax rates was also carried out during 2005-2018 as well as Bulgaria, the Czech Republic, Estonia, Croatia, Hungary, Slovenia. And only two post-socialist countries of the EU - Slovakia and Latvia - increased the tax rate on profits;

2) since 2004, considering the experience of Russia, as well as those of the EU countries such as Estonia, Lithuania and Latvia, a proportional tax on personal income, which is charged at one rate. Simultaneously with Ukraine, such a tax was introduced in Slovakia, and later in Romania (2005), Bulgaria (2008), Czech Republic (2008) and Hungary (2011). At present, some post-socialist EU countries have abandoned the proportional income tax by introducing a 
tax with 2-3 rates - Slovakia (2012 - 19 and 25\%) and Latvia (2017 - 20; 23 and 31.4\%) according to Worldwide Personal Tax and Immigration Guide 2018-19 (2018) and International Tax Highlights 2018 (2018). Ukraine has succeeded in such actions in 2011-2015, returning to the proportional tax in 2016;

3) the establishment from 2016 of the same rate of taxes on corporate profits and on personal income (according to the example of Slovakia in 2004-2012);

4) the gradual increase of excise tax rates (for the implementation of the Association Agreement between Ukraine and the EU).

Characterizing changes in tax policy in Ukraine, it should be noted that they were implemented not only by the innovations in the tax policy of the EU countries, but also by internal factors. In particular, an important reason for the introduction of a proportional income tax was the high level of shadowing of incomes caused by high tax burden on them (the maximum tax rate before the introduction of a proportional tax was $40 \%$ and applied to income exceeding 282 euros) and the disadvantages of tax administration.

Unlike most post-socialist countries of the EU (Czech Republic, Estonia, Croatia, Latvia, Lithuania, Poland, Slovenia and Slovakia), Ukraine did not raise the VAT rate during 2004-2018. Such a policy was due to two reasons - high fiscal efficiency of the tax (Note 2), which is the consequence of the limited use of its reduced rate (only with regard to medicinal products) and the lack of a public consensus on the possibility of raising the VAT rate due to the inherent feature of the tax reimbursement inherent in Ukraine, which for a long time was accompanied by the formation of a budget reimbursement indebtedness, which was a heavy burden for business entities.

Despite the refusal to reconsideration the VAT rate in Ukraine, this tax together with the excise tax formed in 2017 more than $50 \%$ of tax incomes to the consolidated budget; through them, $14.4 \%$ of GDP was redistributed, that is, more than half of GDP, which was redistributed through all tax revenues to the state treasury (27.8\%). Above mantioned shows significant changes in the structure of the Ukrainian tax system in the context of strengthening globalization processes and the resulting narrowing of tax bases on incomes of enterprises and individuals due to capital and labor outflows from the country - the transfer of tax burden from incomes of enterprises and individuals to consumption. This confirms the conclusion James R. Hines Jr., Lawrence H. Summers (2009), according to which the countries with small open economies have a relatively mobile tax base; as a result, they are much less reliant on corporate taxes and personal income taxes, and more on consumption taxes than larger countries.

Along with the changes in the tax system of Ukraine, which corresponded to the general trends of taxation development in the post-socialist countries of the EU, there were innovations that distinguish Ukraine from European countries. It is a question of a decline in the single social contribution rate for entrepreneurs from 41 (weighted average and $36.4 \%$ - effective) to $22 \%$ in the year 2016 and a cancellation of contributions for employees who had previously been paid at a rate of 3.6\%. In fact, there was a reduction in the tax burden both for business and for work, but for work - at times less than for business. The purpose of such a radical step was to withdraw salaries from the shadow.

However, it only succeeded partly in achieving it. As a result, the deficit of the Pension Fund of Ukraine and its financing from the state budget increased (from $35.8 \%$ of total income in 2015 to 55.5 in 2016). The above became an argument for new, even more radical initiatives aimed at canceling a single social contribution, eliminating the Pension Fund and replacing pensions with social assistance to pensioners, which will be paid from state budget revenues. In addition to the Pension, it is proposed to abolish other social funds, which could be an unprecedented blow to social rights and welfare of citizens.

In 2017-2018, a new tax initiative was widely discussed, aimed at further reducing the tax burden on business replacing the tax on profits tax on withdrawn capital. The initiative was included in the program of many presidential candidates in the 2019 elections. According to its authors, the introduction of a new tax will stimulate investment and solve the problem of the hidden withdrawal of capital abroad. However, the hopes for this are not well-founded, as the main reasons for the low investment activity of Ukrainian business and foreign owners of capital, as well as the outflow of Ukrainian capital abroad, as was noted, lie in another. In our opinion, this tax will destroy the system of taxation of corporate profits created by many years of efforts, which meets European standards, and will cause large budget losses, which today has nothing to compensate. In addition, one of the drawbacks of tax is the creation of incentives not to distribute profits, but to invest it even in low-yielding projects, which can lead to economic inefficiencies as Finkenzeller and Spengel (2004) mentioned.

A radical reduction in the rate of the single social contribution in 2016, as well as both initiatives (both on the introduction of a capital tax and on the abolition of the ECT), which have been widely supported in business circles, 
are in fact a manifestation of the tendency towards globalization to minimize the tax burden on capital, although other initiatives are subjectively substantiated by the authors of the initiative. These initiatives are particularly dangerous in the face of significant imbalances in the system of public finances and significant volumes of future debt repayments by the state in the years 2021-2049, which require the Ukrainian governments to conduct sound fiscal policy. It should prevent loss of budget revenues, promote the sustainability of public finances, and introduce effective measures aimed at preventing aggressive tax planning.

Consequently, our analysis allows us to formulate the following hypotheses:

Hypothesis 1 . The development of the Ukrainian tax system is accompanied by a reduction in corporate income tax rates and personal income, including the transition from a progressive to a proportional tax on income and proposals for the replacement of a tax on capital gains tax. Are these changes linked to the increased integration of Ukraine into globalization processes, including economic globalization? At first glance, if the decrease in the tax rate could be explained by the need to attract foreign investment in Ukraine, the decrease in the rate of personal income tax was primarily due to internal factors, in particular, the economic inefficiency of excessive tax burden on rather low labor income.

Hypothesis 2. The development of globalization processes should be accompanied by a decrease in the share of income tax and an increase in the share of PIT in GDP. However, in countries with a high level of shadow economy to which Ukraine belongs, the possibility of transferring the tax burden from capital to labor is limited, and therefore the main tax burden should be for consumption. At the same time, the latter is not due to the increase of the VAT rate (it has not changed in Ukraine since 1995), but due to improved tax administration.

Hypothesis 3. The strengthening of globalization has a mixed impact on the general level of tax burden in different countries of the world: in some countries it is growing, others are reduced or remains unchanged. However, its fluctuations in most countries are negligible. In particular, during 2006-2016 they were only significant in the two EU-Ireland countries, where overall tax revenues declined from 31.4 to $23.3 \%$ of GDP, and in Greece, where they increased from 31.0 to $38.8 \%$. The aforementioned confirms the conclusion Tanzi (1996), regarding the limited effect of globalization and tax competition on general tax revenues. In this context, interest in the study of the relationship between globalization and the dynamics of general tax revenues (tax rate) in Ukraine is of interest.

Hypothesis 4. In theory, the increased involvement of certain countries in the process of globalization and the intensification of interstate tax competition for investment should be accompanied by improved business conditions, including simplification of tax procedures, resulting in a reduction in the number of payments during the year and the cost of preparation time, submission of reports and payment of the main types of taxes and deductions, as well as tax burden on business. In Ukraine, these indicators during the years 2004-2017 have undergone quite significant changes. In particular, the number of payments per year has decreased from 174 to 54, the time to pay taxes - from 2185 to 327,5 hours, the general rate of taxes - from 51,0 to $41,7 \%$. Thus, it is interesting to answer the question whether these changes are connected with the intensification of Ukraine's involvement in globalization processes.

Hypothesis 5. Improving business conditions, including tax simplification, should facilitate the inflow of foreign investment into the country. It is interesting to know if such interconnection can be traced in Ukraine.

Checking these hypotheses using regression analysis gave the following results.

Hypothesis 1. For its verification, two types of regression equations were constructed, in which the dependent variable was (PIT rate, EPT rate), and the independent variable in one model was the globalization index (KOFGl), and in the other - sub-index of economic globalization (KOFEcGl). The corresponding computational results are given in Table 1. The numbers under the coefficients show the results of checking the significance of the coefficients: if this value is less than 0.05, then the corresponding coefficient is significant. All models are adequate. For the analysis of the general rate, we used a fictitious variable q2016, which was only 1 in 2016, when there was a collapse in tax revenues due to the annexation of the Crimea by the Russian Federation and the loss of Ukraine control over part of the territory of Donetsk and Lugansk regions, and 0 - at other periods of time. 
Table 1. Results of hypothesis testing 1

\begin{tabular}{|c|c|c|}
\hline $\begin{array}{l}\text { Independent } \\
\text { variable }\end{array}$ & KOFGI & KOFEcGl \\
\hline PIT rate & 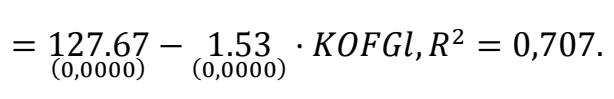 & $=\underset{(0,0000)}{92.93}-\underset{(0,0004)}{1.21} \cdot \mathrm{KOFEcGl}, R^{2}=0,479$. \\
\hline EPT rate & 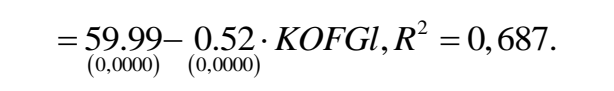 & $=\underset{(0,0000)}{49.27} \underset{(0,0002)}{0.43} \cdot K O F E c G l, R^{2}=0,511$ \\
\hline $\begin{array}{l}\text { Total } \\
\text { rate }\end{array}$ & $=\underset{(0,0000)}{122.72}-\underset{(0,0009)}{0.94} \cdot K O F G l-\underset{(0,0000)}{15,48 \cdot q_{2016}}$, & $=\underset{(0,0000)}{95.79}-\underset{(0,0000)}{0.67} \cdot K O F E c G l-\underset{(0,0020)}{15,22 \cdot} q_{2016}$ \\
\hline rate & $R^{2}=0,707$ & $R^{2}=0,936$ \\
\hline
\end{tabular}

Source: compiled by authors.

For another important tax, VAT, it was impossible to make the same calculations, since its rate did not change throughout the period under investigation.

Analyzing the obtained equations, we can conclude that the processes of globalization have a reverse effect on tax rates in Ukraine. In particular, an increase in the globalization index by 1 leads to a $1.53 \%$ decrease in the PIT rate, a corporate income tax rate of $0.52 \%$, and the overall rate decreases in this case by $0.94 \%$.

Likewise, affects the change in subindex of globalization. If it increases by 1 , then the rate of the personal income tax is reduced by $1.21 \%$, the profit tax rate - by $0.43 \%$, and the general rate - by $0.67 \%$.

Thus, hypothesis 1 can be considered as confirmed: in Ukraine, there is a link between globalization and its tax consequences, such as lower rates of corporate income taxes and individual incomes. It should be noted that the global index of globalization has about a quarter more influence than its subindex. Therefore, Ukraine's tax system is more responsive to the overall economic development than globalization.

Hypothesis 2. In checking this hypothesis, we apply a similar algorithm to the previous version. The results of calculating the magnitude of the impact of globalization indices on the share of taxes in the runway (PIT, EPT, VAT) are given in Table 2. All models are adequate.

Table 2. Results of hypothesis testing 2

\begin{tabular}{|c|c|c|}
\hline $\begin{array}{c}\text { Independent } \\
\text { variable }\end{array}$ & KOFGl & KOFEcGl \\
\hline $\begin{array}{c}\text { PIT as } \% \text { of } \\
\text { GDP }\end{array}$ & $=-\frac{1.04}{(0,1353)}+\underset{(0,0000)}{0.079} \mathrm{KOFGl}, R^{2}=0,758$. & $=\underset{(0,7450)}{0.20}+\underset{(0,0000)}{0.073} \cdot \mathrm{KOFEcGl}, R^{2}=0,695$. \\
\hline $\begin{array}{c}\text { EPT as } \% \text { of } \\
\text { GDP }\end{array}$ & 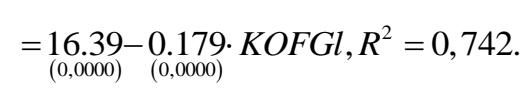 & 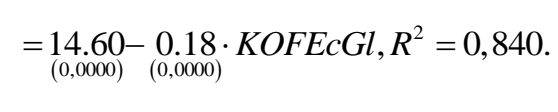 \\
\hline $\begin{array}{c}\text { VAT as \% } \\
\text { of GDP }\end{array}$ & 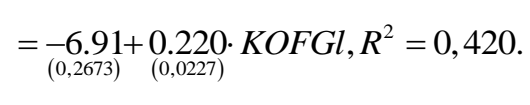 & 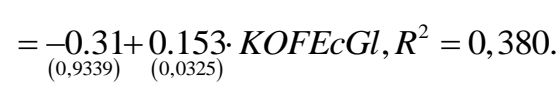 \\
\hline
\end{tabular}

Source: compiled by authors.

As we see, the impact of globalization has a different effect on the share of various taxes in GDP. In particular, an increase in the index of globalization by 1 leads to an increase in the share of personal income tax of $0.079 \%$ and VAT - by $0.22 \%$ and a decrease in the share of profit tax in GDP by $0.179 \%$. The interconnection with the sub-index of economic globalization is almost the same: the growth of the subindex by 1 leads to an increase in the share of PIT in GDP by $0.073 \%$, VAT - by $0.153 \%$, and a decrease in the share of profit tax in GDP by $0.18 \%$. Consequently, 
as expected, the development of globalization processes in Ukraine is accompanied by the transfer of the tax burden from capital to labor (to a lesser extent) and consumption (by a greater degree).

Hypothesis 3. In this hypothesis, we will determine the dependence of the tax coefficient on the level of globalization (Table 3). It should be noted that the impact of the subindex at once was not significant, given the corresponding model, although it is adequate, nevertheless, the coefficient for the variable KOFEcGl is not significant.

Table 3. Results of hypothesis testing 3

\begin{tabular}{|c|c|c|}
\hline $\begin{array}{l}\text { Independent } \\
\text { variable }\end{array}$ & KOFGl & KOFEcGl \\
\hline Total taxes & $\begin{array}{l}=-7.81+\underset{(0,3745)}{0.5908} \cdot \mathrm{KOFGl}-5,49 \cdot q_{2016}, \\
R^{2}=0,644 .\end{array}$ & $\begin{array}{l}=\underset{(0,0014)}{43.96} \underset{(0,3866)}{0.139} \cdot \mathrm{KOFEcGl}-4,003 \cdot q_{2016}, \\
R^{2}=0.630 .\end{array}$ \\
\hline
\end{tabular}

Source: compiled by authors.

As we see, the growth of the globalization index by 1 leads to an increase in the tax rate by $0.598 \%$. At the same time, the sub-index of globalization has no direct effect due to the insignificance of the corresponding coefficient $(0.139)$.

Thus, hypothesis 3 is partially confirmed. Globalization really has an impact on the tax rate, but the index of economic globalization does not have such an effect. This once again proves that the Ukrainian economy is more responsive to the general than economic globalization.

Hypothesis 4. Likewise, to the previous cases, consider regressions that show the impact of globalization indices on the number of mandatory payments (Payments) and the time required to pay taxes (Time). The results of calculations are given in Table 4.

Table 4. Results of hypothesis testing 4

\begin{tabular}{|c|c|c|}
\hline $\begin{array}{l}\text { Independent } \\
\text { variable }\end{array}$ & KOFGl & KOFEcGl \\
\hline $\begin{array}{c}\text { Payments } \\
\text { (number per } \\
\text { year) }\end{array}$ & 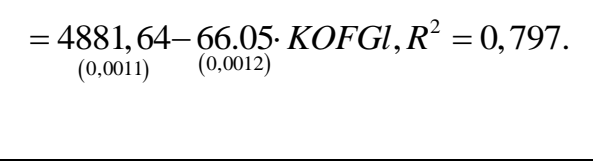 & 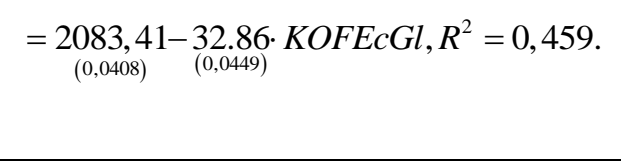 \\
\hline $\begin{array}{l}\text { Time (hours } \\
\text { per year) }\end{array}$ & $=\underset{(0,0000)}{17846,82}-\underset{(0,0000)}{237.61 \cdot K O F G l, R^{2}}=0,937$. & $=\underset{(0,0000)}{11797,85-183.37}{ }_{(0,0000)}$ KOFEcGl, $R^{2}=0,916$. \\
\hline
\end{tabular}

Source: compiled by authors.

All regressions are adequate, which allows conducting an appropriate analysis. The growth of the globalization index by 1 leads to a reduction in the number of required payments by about 66 , and the time to pay taxes - about 237.6 hours. The effect of subindex change is more modest, in particular its increase by 1 leads to a decrease in the number of mandatory payments by 33 , and the time to pay taxes - 183 hours.

Thus, it can be argued that hypothesis 4 is confirmed: the development of globalization processes in the world forces Ukraine to become more competitive by offering lighter and more transparent tax procedures.

Hypothesis 5. To test this hypothesis, we construct a model of the dependence of the growth of direct foreign investments (PII_in) on the share of the tax on profit (TTR), the number of payments (Payments) and time to pay taxes (Time). The growth of direct foreign investment is used in the model due to the unsteadiness of the PII_in indicator. The model looks like (2):

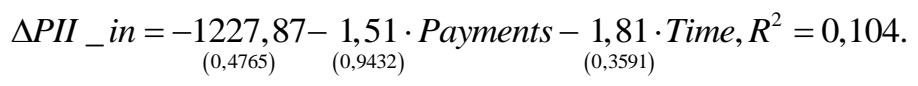


This model is inadequate, and all coefficients are insignificant. Consequently, hypothesis 5 is not confirmed. A comparison of the dynamics of FDI in Ukraine with the change of the country's position in the Doing Business rating by category of taxation shows that their significant improvement in recent years has not contributed to the inflow of investments into Ukraine. The main factors determining the investment climate in the country are military actions on the territory of the Donbas, the level of corruption and lack of fair legal proceedings, which threaten the protection of the interests of foreign investors in the courts, the lack of a weak level of specification and protection of property rights that raises the risk of its redistribution, absence of transparent competitive market environment. For the permanence of these factors, no changes in the tax system will stimulate a strong influx of foreign investment into the country.

\section{Conclusions}

1. The theoretical analysis of the issue discussed in this article allowed us to identify, along with the global consequences of globalization and international tax competition for tax systems, investigated by Western scholars, the peculiarities of the effects of globalization for a small open economy, whose tax policy is shaped not only by tax competition, but also significant fiscal constraints, significant social obligations of the state, underdeveloped institutions, large-scale corruption. Such features can be considered: significant losses of the state are not so much from the reduction of tax rates, as from the erosion of tax incomes bases, which is the result of a combination of the negative effects of external and internal factors - the withdrawal of capital (not so much legal, as illegal, without paying taxes) and labor resources from the country, as well as large-scale tax evasion and shadow revenues within the country; a threat to the escalation of the policy of low rates (the emergence of signs of "race to the bottom") - a radical reduction in the rate of the single social contribution in 2016, as well as initiatives to replace the tax on income tax on capital raised and the abolition of the ECT, which have found wide support in business circles and in the politics; transfer of tax burden from consumption income, which currently forms in Ukraine more than 50\% of tax incomes to the consolidated budget.

2. Empirical analysis showed:

- the tax system in Ukraine is dependent on global influences. Growth of the globalization index is accompanied by a reduction in the rates of corporate income tax and personal income tax, a change in the structure of the tax system in the direction of transferring the tax burden from capital to labor and, to a greater extent, on consumption, improvement of business conditions (by reducing the amount of tax payments and time spent on their implementation);

- the strengthening of the incorporation of Ukraine in the globalization processes, despite the reduction of taxes on the main factors of production, is accompanied by an increase in the general level of tax burden on the economy (tax rate). The above mantioned is a consequence of the increase of other taxes, including - the excise, caused by the internal needs of Ukraine (implementation of the policy of fiscal consolidation, caused by a large public debt, and the increase of defense expenditures) and its international obligations (EU-Association Agreement);

- the tax system in Ukraine is much stronger (about 25\%) influenced by the general index of globalization in comparison with its subindex characterizing the economic component of globalization. Obviously, this is due to the greater influence on taxation in Ukraine of other components of globalization - political and social;

- improving the business environment, including in the context of tax payments, is not able to significantly stimulate foreign direct investment in Ukraine. It is obvious that the occupations of the country's territory, corruption risks, judicial problems, etc. are significant obstacles on their way.

In the future, with the growth of the transparency of the Ukrainian economy, the strengthening of its integration into the global environment, the impact of the latter on the national tax policy will increase. In this context, the signing by Ukraine of the Association Agreement with the EU plays a twofold role. On the one hand, it promotes globalization through the creation of a comprehensive free trade area and the introduction of a visa-free regime. On the other hand, it is a deterrent to attempts to engage in negative tax competition through the commitment of our country to adapt national tax legislation to EU legislation. Hence, tax policy in Ukraine will be shaped under the decisive influence of external factors such as tax competition and tax harmonization.

Considering the proclaimed course of Ukraine`s integration into EU in the development of fiscal policy, the Ukrainian Government has to increasingly focus on the trend of tax evasion in post-socialist countries of the EU to strengthen the position of our country in tax competition with this group of countries. The significance of this factor will increase as the negative impact on the movement factors of production between Ukraine and European countries is reduced by non-tax factors that are now decisive, substantially weakening the impact of tax competition. 


\section{References}

Augbaka, M., Awujola, A., \& Shcherbyna, T. (2019). Economic Development, Foreign Aid and Poverty Reduction: Paradigm in Nigeria. SocioEconomic Challenges, 3(4), 5-12. https://doi.org/10.21272/sec.3(4).5-12.2019

Average Salary in European Union. (2018). Reinis Fischer research. Retrieved April 11, from https://www.reinisfischer.com/average-salary-european-union-2018

Bilan, Y., Lyeonov, S., Lyulyov, O., \& Pimonenko, T. (2019a). Brand management and macroeconomic stability of the country. [Zarządzanie marką i stabilność makroekonomiczna kraju] Polish Journal of Management Studies, 19(2), 61-74. https://doi.org/10.17512/pjms.2019.19.2.05

Bilan, Y., Lyeonov, S., Vasylieva, T., \& Samusevych, Y. (2018). Does tax competition for capital define entrepreneurship trends in eastern europe?. Online Journal Modelling the New Europe, (27), 34-66. https://doi.org/10.24193/OJMNE.2018.27.02

Bilan, Y., Raišienè, A. G., Vasilyeva, T., Lyulyov, O., \& Pimonenko, T. (2019c). Public governance efficiency and macroeconomic stability: Examining convergence of social and political determinants. Public Policy and Administration, 18(2), 241-255. https://doi.org/10.13165/VPA-19-18-2-05

Bilan, Y., Vasilyeva, T., Lyulyov, O., \& Pimonenko, T. (2019b). EU vector of ukraine development: Linking between macroeconomic stability and social progress. International Journal of Business and Society, 20(2), 433-450.

Buriak, A., Lyeonov, S., \& Vasylieva, T. (2015). Systemically important domestic banks: An indicator-based measurement approach for the ukrainian banking system. Prague Economic Papers, 24(6), 715-728. https://doi.org/10.18267/j.pep.531

Cebula, J., Chygryn, O., Chayen, S. V., \& Pimonenko, T. (2018). Biogas as an alternative energy source in ukraine and israel: Current issues and benefits. International Journal of Environmental Technology and Management, 21(5-6), 421-438. https://doi.org/10.1504/IJETM.2018.100592

Chygryn, O., Pimonenko, T., Luylyov, O., \& Goncharova, A. (2018). Green bonds like the incentive instrument for cleaner production at the government and corporate levels: Experience from EU to ukraine. Journal of Environmental Management and Tourism, 9(7), 1443-1456. https://doi.org/10.14505/jemt.v9.7(31).09

Cohen, A. (2008). The Skill Composition of Immigrants and the Generosity of the Welfare State: Free vs. Policy-Controlled Migration. NBER Working Paper, October, W14459, 37.

Devereux, M. P., \& Loretz, S. (2013). What Do We Know about Corporate Tax Competition?. National Tax Journal, $66(3), 745-774$.

Direct investments on the principle of orientation (flows). National Bank of Ukraine. Department of Statistics and Reporting. Retrieved April 26, 2019, from https://bank.gov.ua/doccatalog/document?id=29318281

Doing Business. International Bank for Reconstruction and Development/The World Bank. Retrieved March 22, 2019 ,

from http://www.doingbusiness.org/content/dam/doingBusiness/media/Annual-Reports/English/DB13-full-report.pdf

Druhov, O., Druhova, V., \& Pakhnenko, O. (2019). The Influence of Financial Innovations on EU Countries Banking Systems Development. Marketing and Management of Innovations, 3, 167-177. https://doi.org/10.21272/mmi.2019.3-13

Egger, P., Nigai, S., \& Strecker, N. (2016). The impact of globalisation on tax structures in OECD countries, 21 May.

Finkenzeller, M., \& Spengel, Ch. (2004). Measuring the effective levels of company taxation in the new member States: A quantitative analysis. European Commission, Taxation Papers, Working paper № 7.

Genschel, P., \& Seelkopf, L. (2016, June). Globalization and Tax Policy. In Melvin Dubnick, \& Domonic Bearfield (Eds.), Encyclopedia of Public Administration and Public Policy (3rd ed.). Publisher: Taylor and Francis.

Gyglia, S., Haelgb, F., \& Sturmb, J.-E. (2018). The KOF Globalisation Index - Revisited. KOF Working Papers, № 439, February.

Hellier, J. (2018). Globalization, income tax structure and the redistribution-progressivity tradeoff, April. 
In "tax oases" hidden over \$ 21 trillion. Retrieved March, 20, 2019, from https://ipress.ua/news/u_podatkovyh_oazah_shovano_ponad_21_trylyon_5021.html

International Tax Highlights 2018. Deloitte. Retrieved April 10, 2019, from https://www2.deloitte.com/ua/en.html

James, R., H. Jr., \& Lawrence, H. S. (2009). How Globalization Affects Tax Design. NBER Working Paper № 14664, January, 39.

Keuschnigg, C. (2009). Corporate Taxation and the Welfare State. CESifo Working Paper, № 2557, 29.

Kleven, H., Landais, C., \& Saez, E. (2013). Taxation and International Mobility of Superstars: Evidence from the European Football Market. American Economic Review, 103, 1892-1924.

KOF Globalisation Index 2018. Swiss Economic Institute. Retrieved February 2, 2019, from https://www.ethz.ch/content/dam/ethz/special-interest/dual/kof-dam/documents/Globalization/2018/Data_2018_ 2.xlsx

Kwilinski, A. (2019). Implementation of blockchain technology in accounting sphere. Academy of Accounting and Financial Studies Journal, 23(Special Issue 2), Retrieved from www.scopus.com

Luković, S. (2015, July - September). The impact of globalization on the characteristics of European countries' tax systems. Economic Annals, LX(206), 117-139.

Merkulova, T. (2013). The Impact of International Tax Competition on Tax System Reform: Models and Results. In Mayburov, I. A., Yu. B., Ivanova, L.L. \& Taragul, K. A. (Eds.), The Economics of Tax Reforms: monograph (pp. 83-93).

Miller, A. D. (2019). Current Mining Taxation Policy Implemented by both Mongolia and Kazakhstan: The Development Comparatives between Ulaanbaatar and Astana. Business Ethics and Leadership, 3(2), 39-52. https://doi.org/10.21272/bel.3(2).39-52.2019

Minimum wage statistics. $\quad$ Retrieved $\quad$ March 20, 2019, $\quad$ from http://ec.europa.eu/eurostat/statistics-explained/images/a/a8/Minimum_wage_statistics_22.2.2018.xlsx

Onaran, Ö., \& Boesch, V. (2014, January). The effect of globalization on the distribution of taxes and social expenditures in Europe: Do welfare state regimes matter?. Environment and Planning A: Economy and Space, 46(2), 373-397.

Report on Foreign Direct Investment in Ukraine. 2011 year Ernst \& Young. Retrieved March 21, 2019, from https://regionet.org.ua/files/Report_on_direct_investent_in_Ukraine_ErnstYoung_2011_ua.pdf

Reports on implementation of the consolidated budget of Ukraine. State Treasury of Ukraine. Retrieved February 25, 2019, from https://www.treasury.gov.ua/ua/file-storage/vikonannya-derzhavnogo-byudzhetu

Reports on the implementation of the budget of the Pension Fund of Ukraine. Retrieved March 4, 2019, from https://www.pfu.gov.ua/category/informatsiya/byudzhet/arhiv-zvitnist-byudzhet/

Retrospective analysis of data on volumes of direct foreign investments in which the ultimate controlling investor is a resident (round tripping) for 2010-2017 years. Retrieved March 20, 2019, from https://bank.gov.ua/doccatalog/document?id=73849830

Reuven, S. Avi-Yonah. (2000). Globalization, Tax Competition, and the Fiscal Crisis of the Welfare State. Harv. $L$. Rev., 113(7), 1573-1676.

Roxan, I. (2012). Limits to globalisation: some implications for taxation, tax policy, and the developing world. LSE law, society and economy working paper series, 3. Law Department, London School of Economics and Political Science, 47.

Singh, S. N. (2019a). Impact of Value Added Tax on Business Enterprises: A Case of Mettu Town. Financial Markets, Institutions and Risks, 3(4), 62-73. https://doi.org/10.21272/fmir.3(4).62-73.2019

Singh, S. N. (2019b). The Analysis of Value Added Tax (Vat) to Increasing Government Revenue in Ethiopia. Financial Markets, Institutions and Risks, 3(2), 115-127. https://doi.org/10.21272/fmir.3(2).115-127.2019

State Statistics Service of Ukraine. Retrieved March 5, 2019, from http://www.ukrstat.gov.ua/

Tanzi, V. (1996). Globalization, Tax Competition and the Future of Tax Systems. IMF Working Paper № 96/141, 21. 
Tanzi, V. (2005). Globalization, Tax System, and the Architecture of the Global Economic System. Inter-American Development Bank, 23.

Tanzi, V., \& Zee, H. (2001). Tax Policy for Developing Countries / International Monetary Fund.

Taxation trends in the European Union: Data for the EU Member States, Iceland and Norway: 2018 edition. Luxembourg: Publications Office of the European Union. Retrieved March 5, 2019, from https://ec.europa.eu/taxation_customs/sites/taxation/files/taxation_trends_report_2018.pdf

Tiutiunyk, I., Kobushko, I., Ivaniy, O., \& Flaumer, A. (2019). Innovations in the Management of Tax Gaps in the Economy: Foreign Economic Component. Marketing and Management of Innovations, 3, 112-125. https://doi.org/10.21272/mmi.2019.3-09

Voronkova, O., Hordei, O., Barusman, A. R. P., \& Ghani, E. K. (2019). Social Integration As A Direction For Humanization Of Economic Relations And Improvement Of Social Welfare. SocioEconomic Challenges, 3(4), 52-62. https://doi.org/10.21272/sec.3(4).52-62.2019

Wilson, J. D. (1999). Theories of Tax Competition. National Tax Journal, 52, 269-304.

Worldwide Personal Tax and Immigration Guide 2018-19. Ernst \& Young. November 2018. Retrieved April 11, 2019 , from https://www.ey.com/Publication/vwLUAssets/ey-2018-19-worldwide-personal-tax-and-immigration-guide/\$FI LE/ey-2018-19-worldwide-personal-tax-and-immigration-guide.pdf

Zodrow, G. R. (2003) Tax Competition and Tax Coordination in the European Union. International Tax and Public Finance, 10, 651-671.

\section{Notes}

Note 1. In the OECD financial statistics, this indicator is called "tax ratio", in the EU statistical collections it is called "Total taxes (including compulsory actual social contributions) as\% of GDP".

Note 2. The share of VAT in GDP in Ukraine in 2017 compared to 2016 rose from 9.9\% to $10.5 \%$. It exceeds the fiscal efficiency of not only two direct taxes - the income of individual and the profit of enterprise taken together, but also the average indicator characterizing the share of VAT in GDP in the post-socialist countries-members of the EU (8.4\% in 2016) and developed the countries of the EU with the same level of standard rate of tax (Austria - 7,7, Great Britain - 6,8 and France - 6,9\%). In 2016, only one EU country - Croatia (13\% of GDP), with a higher standard tax rate $(25 \%)$ had fiscal efficiency of the VAT higher than in Ukraine.

\section{Copyrights}

Copyright for this article is retained by the author(s), with first publication rights granted to the journal.

This is an open-access article distributed under the terms and conditions of the Creative Commons Attribution license (http://creativecommons.org/licenses/by/4.0/). 